\title{
Efektivitas Seminar pada Perubahan Sikap Ibu dalam Pemberian Dukungan Nutrisi dan Stimulasi selama Pemantauan Tumbuh Kembang
}

Soedjatmiko, ${ }^{*}$ Hartono Gunardi, ${ }^{*}$ Rini Sekartini, ${ }^{*}$ Bernie Endyarni Medise, ${ }^{*}$ Ikhsan, ${ }^{* *}$ Yulianti Wibowo, ${ }^{* * *}$ Ray Wagiu Basrowi ${ }^{* * *}$ *Departemen Ilmu Kesehatan Anak Fakultas Kedokteran Universitas Indonesia, ${ }^{* *}$ Fakultas Kedokteran Universitas Indonesia, ${ }^{* * *}$ Nestle Nutrition Institute Indonesia

Latar belakang. Kualitas tumbuh kembang balita ditentukan oleh nutrisi, kasih sayang, stimulasi, dan perlindungan terhadap penyakit. Ibu sebagai pengasuh utama anak berperan penting mengoptimalkan pertumbuhan dan perkembangan anak, sehingga harus memiliki sikap yang baik tentang pemantauan tumbuh kembang saat kunjungan ke tenaga kesehatan. Peningkatan pengetahuan Ibu dapat dilakukan dengan edukasi dan pelatihan.

Tujuan. Menganalisis efektivitas seminar pada perubahan sikap ibu dalam pemberian dukungan nutrisi dan stimulasi selama pemantauan tumbuh kembang.

Metode. Penelitian desain potong lintang dengan kuesioner pre dan post intervensi dilakukan pada ibu dengan balita. Perubahan sikap ibu dievaluasi dalam pemantauan tumbuh kembang anaknya. Intervensi berupa seminar mengenai kesehatan anak yang diadakan di 6 kota besar di Indonesia dengan purposive sampling peserta yang mengisi lengkap kuesioner. Analisis data digunakan metode paired T-test dalam software IBM SPSS statistics versi 22.

Hasil. Terdapat 617 ibu yang mengisi lengkap kuesioner yang diberikan dalam seminar. Terjadi peningkatan yang bermakna (beda mean $-0,15 \pm 0,26 ; 95 \%$ CI $-0,17$ sampai-0,13; $\mathrm{p}<0,001)$ pada rerata skor sikap ibu setelah mengikuti seminar yang diadakan oleh peneliti. Sumber informasi yang penting dan berkesan, antara lain, televisi, gawai, media sosial, tenaga kesehatan, dan seminar oleh tenaga kesehatan.

Kesimpulan. Pemberian seminar oleh tenaga kesehatan mengubah sikap ibu pada pengasuhan anak selama pemantauan tumbuh kembang dengan efektif ( $\mathrm{p}<0,001)$. Sari Pediatri 2017;19(4):201-8

Kata Kunci: seminar, sikap ibu, pengasuhan, nutrisi, tumbuh kembang

\section{The Effectiveness of Seminar in Changing Mothers' Attitude Toward Nutrition and Stimulation Support During Growth and Development Monitoring}

Soedjatmiko, ${ }^{*}$ Hartono Gunardi, ${ }^{*}$ Rini Sekartini, ${ }^{*}$ Bernie Endyarni Medise, ${ }^{*}$ Ikhsan, ${ }^{* *}$ Yulianti Wibowo, ${ }^{* * *}$

Ray Wagiu Basrowi ${ }^{* *}$

Background. Child growth and development quality are determined by nutrition, love, stimulation and disease protection. Mothers as the main caregiver, have an important role to optimize children's growth and development, thus should have good attitude and knowledge about the importance of growth and development monitoring during visits to healthcare workers. An increase of knowledge could be obtained by education and training.

Objective. Analyze the effectiveness of seminar in changing mothers' attitude towards nutrition and stimulation during growth and development monitoring.

Methods. A cross-sectional study was done using pre and post-intervention questionnaires on mothers to evaluate the change in their attitudes towards their children's growth and development monitoring. A seminar was held as an intervention in six cities in Indonesia with purposive sampling from an attendant who completes the questionnaire. Data taken were analyzed using paired T-test in IBM SPSS statistics version 22 software.

Results. There were 617 mothers who completed questionnaires given before and after the seminar. Mothers' attitude average score was significantly increased (Mean difference $-0.15 \pm 0.26 ; 95 \%$ CI -0.17 to- $0.13 ; \mathrm{p}<0.001$ ) after seminar. Sources of meaningful information for mothers included television, handphone, social media, healthcare workers, and seminar by healthcare workers.

Conclusion. Seminar by healthcare workers can change mothers' attitude towards nurturing their children in an effective way. Sari Pediatri 2017;19(4):201-8

Keywords: seminar, mothers' attitude, nurture, nutrition, growth and development

Alamat korespondensi: DR. Dr. Soedjatmiko, SpA(K), MSi. Departemen Ilmu Kesehatan Anak Fakultas Kedokteran Universitas Indonesia. J1. Diponegoro no.71. Email: soedjat3@yahoo.com 


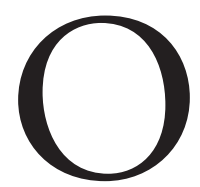
rang tua berperan besar terhadap pertumbuhan dan perkembangan anak, terutama pada saat berada di bawah usia lima tahun atau balita. Dalam pengasuhan anak oleh ibu, kualitas tumbuh kembang anak ditentukan oleh kualitas nutrisi, kasih sayang, stimulasi, dan perlindungan terhadap penyakit. Pengetahuan dan sikap ibu memengaruhi perilaku ibu dalam menerapkan hal tersebut . ${ }^{1,2}$ Tingkat pendidikan dan pengetahuan ibu sebagai pengasuh utama dalam lingkungan mikro mengenai tumbuh kembang anak berperan dalam kesehatan anak. ${ }^{3}$ Peningkatan pengetahuan ibu dapat dilakukan dengan edukasi dan pelatihan dalam bentuk seminar, workshop, focused group discussion, konsultasi individu, pendampingan, ataupun intervensi lainnya baik secara individu maupun kelompok. ${ }^{1,2,4}$

Ibu merupakan tokoh sentral dalam tahap perkembangan seorang anak. Ibu berada dalam lingkungan terkecil, yaitu mikro yang berperan sebagai pendidik pertama dan utama dalam keluarga. Pengetahuan ibu mengenai cara mengasuh anak secara baik dan sesuai dengan kebutuhan pertumbuhan dan tahapan perkembangan anak penting untuk mengoptimalkan tumbuh kembang anak..$^{5-7}$ Peningkatan pengetahuan dan perubahan sikap ibu dipengaruhi oleh beberapa faktor, yaitu sumber informasi, frekuensi paparan informasi, pendidikan ibu, pengalaman ibu mengasuh anak, dan tingkat ekonomi keluarga. ${ }^{8,9}$

Usia 1 hingga 5 tahun merupakan periode penting karena terjadi pertumbuhan dan perkembangan yang pesat, baik fisik, kemampuan gerak, komunikasi, kognitif, emosi, dan kemandirian. Untuk mengetahui kualitas pertumbuhan fisik, ibu harus mempunyai sikap yang baik tentang pentingnya pemantauan berkala berat badan, tinggi badan, dan lingkar kepala anak umur 1-5 tahun ketika datang ke dokter, Puskesmas, atau Posyandu. Kualitas tumbuh kembang tersebut dipengaruhi oleh faktor nutrisi, kasih sayang, dan stimulasi dari keluarga. ${ }^{5,6}$ Oleh karena itu, penelitian ini ingin mengetahui bagaimana sikap ibu mengenai nutrisi, terutama ASI dan makanan pendamping ASI, kasih sayang dan stimulasi bermain setelah pemberian edukasi berupa seminar.

\section{Metode}

Penelitian dengan desain potong lintang, digunakan kuesioner pre dan post intervensi, dilakukan pada ibu untuk mengevaluasi perubahan sikap ibu terhadap pemberian nutrisi, stimulasi dan kasih sayang dalam pemantauan tumbuh kembang anak. Intervensi yang dilakukan berupa seminar seputar pentingnya nutrisi, stimulasi dan kasih sayang dalam pemantauan tumbuh kembang anak oleh para ahli di bidang kesehatan anak yang terdiri atas dokter konsultan tumbuh kembang anak, ahli nutrisi, dan psikolog anak. Seminar dilakukan selama 4 jam dengan menampilkan tiga topik kesehatan anak dalam setiap seminar, antara lain, pentingnya pemberian nutrisi, stimulasi, dan kasih sayang untuk anak. Seminar disampaikan dalam bentuk interaktif antara narasumber dan peserta seminar dengan alat bantu tayangan presentasi. Penelitian ini dilakukan di enam kota besar di Indonesia, yaitu Banjarmasin, Pekanbaru, Malang, Palembang, Balikpapan, dan Semarang sejak Juni hingga Desember 2016.

Populasi target pada penelitian ini adalah ibu yang memiliki anak balita yang menjadi peserta dalam seminar. Subjek akan dieksklusi bila tidak melengkapi pengisian kuesioner sebelum ataupun sesudah seminar. Kuesioner dibuat oleh tim peneliti dan telah diuji coba kelayakannya. Kuesioner mencakup informasi subjek, pernyataan mengenai pentingnya nutrisi, stimulasi, dan kasih sayang pada pemantauan tumbuh kembang untuk mengoptimalkan potensi anak.

Variabel yang diteliti adalah perubahan nilai sikap ibu berdasarkan pilihan ibu pada pernyataan yang paling sesuai dengannya. Pengisian kuesioner dilakukan oleh masing-masing calon subjek sebelum dan sesudah mengikuti seminar. Bila calon subjek tidak mengerti maksud pernyataan atau cara menandai kuesioner, calon subjek akan dijelaskan oleh asisten penelitian.

Kuesioner dibedakan dengan dua warna untuk diberikan pada waktu yang berbeda. Kuesioner pertama diisi sebelum pembicara menyampaikan materi, sedangkan kuesioner kedua diisi setelah seluruh materi seminar disampaikan. Hanya kuesioner yang berisi lengkap yang dimasukkan dalam pengumpulan data. Metode paired T-test dalam software IBM SPSS statistics versi 22 digunakan sebagai analisis data.

Penelitian ini telah mendapat hasil kaji etik dan surat keterangan lolos etik oleh komite etik Fakultas Kedokteran Universitas Indonesia. 


\section{Hasil}

Sebanyak 1090 ibu mengikuti seminar tentang pentingnya nutrisi, stimulasi dan kasih sayang dalam pemantauan tumbuh kembang anak, dan terdapat $617(61,6 \%)$ subjek yang mengisi kuesioner penelitian dengan lengkap. Jumlah subjek di tiap kota tertera pada Gambar 1.

Gambar 1 menggambarkan jumlah peserta seminar pada tiap kota dengan jumlah peserta paling banyak di Kota Malang (250 subjek), dan paling sedikit di Kota Balikpapan (100 subjek). Jumlah subjek yang terekrut paling banyak berasal dari Kota Malang (178 subjek) dan paling sedikit berasal dari Kota Balikpapan (43 subjek).

Karakteristik subjek tertera pada Tabel 1 . Karakteristik dipisahkan berdasarkan usia, pendidikan, pekerjaan, jumlah penghasilan keluarga, pengasuhan

Tabel 1. Karakteristik subjek

\begin{tabular}{lcc}
\hline Item karakteristik & Kriteria & Nilai \\
\hline Usia ibu, tahun & Rerata (SD) & $32(6,6)$ \\
Pendidikan ibu,\% & Tamat SMA & 40,5 \\
& D3, S1 & 52,8 \\
Pekerjaan ibu,\% & Tidak bekerja & 51,8 \\
& Bekerja di luar rumah & 48,2 \\
Penghasilan keluarga, \% & <p. 2.000.000 & 27,1 \\
& Rp.2.000.000 - Rp. 5.000.000 & 54,3 \\
& $>$ Rp. 5.000.000 & 18,6 \\
Mengasuh anak secara langsung, \% & Ya & 78,9 \\
& Tidak & 21,2 \\
Jumlah anak, \% & 1 & 57,0 \\
& 2 & 30,6 \\
& 3 atau lebih & 12,4
\end{tabular}

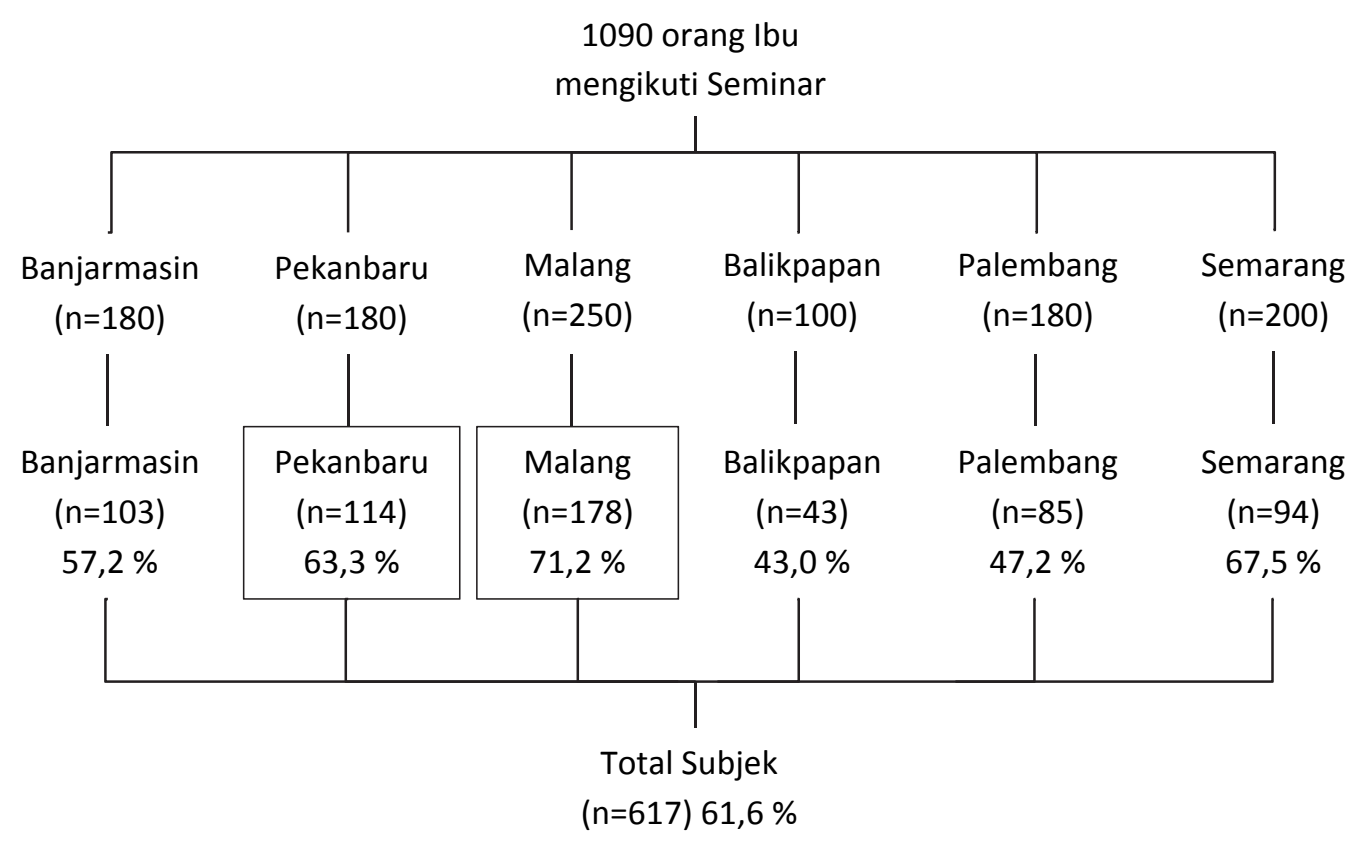

Gambar 1. Jumlah peserta seminar dan subjek penelitian tiap kota 
Soedjatmiko dkk: Efektivitas seminar pada perubahan sikap ibu dalam pemberian dukungan nutrisi dan stimulasi selama pemantauan tumbuh kembang

Tabel 2. Sikap ibu terhadap pentingnya pemantauan tumbuh kembang balita

\begin{tabular}{|c|c|c|c|c|c|c|}
\hline No & Pertanyaan & $\begin{array}{c}\text { Sebelum } \\
\text { Rerata }(S D)\end{array}$ & $\begin{array}{c}\text { Sesudah } \\
\text { Rerata (SD) }\end{array}$ & $\begin{array}{l}\text { Beda Rerata } \\
\text { (SD) }\end{array}$ & CI 95\% & $\mathrm{p}$ \\
\hline 1 & $\begin{array}{l}\text { Apakah Ibu meminta anak ditimbang berat } \\
\text { badannya ketika ke dokter/ pusksesmas / } \\
\text { posyandu? }\end{array}$ & $2,88(0,44)$ & $2,92(0,33)$ & $-0,04(0,41)$ & $-0,07--0,01$ & 0,015 \\
\hline 2 & $\begin{array}{l}\text { Apakah Ibu meminta anak diukur panjang } \\
\text { badannya ketika ke dokter/ puskesmas/ } \\
\text { posyandu? }\end{array}$ & $2,56(0,33)$ & $2,73(0,59)$ & $-0,17(0,69)$ & $-0,22 \sim-0,11$ & $<0,001$ \\
\hline 3 & $\begin{array}{l}\text { Apakah Ibu meminta anak diukur lingkar } \\
\text { kepalanya ketika ke dokter/ puskesmas/ } \\
\text { posyandu? }\end{array}$ & $1,86(1,14)$ & $2,32(0,96)$ & $-0,46(1,05)$ & $-0,54--0,38$ & $<0,001$ \\
\hline 4 & $\begin{array}{l}\text { Apakah Ibu perlu menanyakan kemampuan } \\
\text { bicara anak ketika ke dokter/ puskesmas/ } \\
\text { posyandu? }\end{array}$ & $2,35(0,91)$ & $2,5(0,82)$ & $-0,15(0,84)$ & $-0,21 \sim-0,08$ & $<0,001$ \\
\hline 5 & $\begin{array}{l}\text { Apakah Ibu perlu menanyakan kemampuan } \\
\text { anak mengeri perintah ketika ke dokter/ } \\
\text { puskesmas/ Posyandu? }\end{array}$ & $2,26(0,93)$ & $2,41(0,86)$ & $-0,15(0,86)$ & $-0,21 \sim-0,08$ & $<0,001$ \\
\hline \multirow[t]{2}{*}{6} & $\begin{array}{l}\text { Apakah Ibu perlu menanyakan kemampuan } \\
\text { anak bermain dengan benda dan anak lain } \\
\text { ketika ke dokter/ puskesmas/ Posyandu? }\end{array}$ & $2,18(1,00)$ & $2,23(1,03)$ & $-0,05(1,14)$ & $-0,14 \sim 0,04$ & 0,26 \\
\hline & $\begin{array}{l}\text { Rerata skor sikap ibu pada pentingnya } \\
\text { pemantauan tumbuh kembang }\end{array}$ & $2,35(0,60)$ & $2,54(0,54)$ & $-0,19(0,52)$ & $-0,23 \sim-0,15$ & $<0,001$ \\
\hline
\end{tabular}

Keterangan: $0-0,75=$ tidak peduli; $0,76-1,5=$ sangat kurang peduli; $1,51-2,25=$ kurang peduli; $2,26-3=$ peduli. $p<0,05=$ signifikan

anak secara langsung, dan jumlah anak yang dimiliki.

Berdasarkan Tabel 1 didapatkan usia subjek memiliki rata-rata berusia $32(6,6)$ tahun. Sebagian besar pendidikan terakhir subjek berupa D3 atau S1 $(52,8 \%)$, dan tidak bekerja $(51,8 \%)$ dengan penghasilan keluarga cukup, yaitu di atas Rp. $2.000 .000,00(>72,9 \%)$, dan mengasuh anaknya secara langsung $(78,9 \%)$. Mayoritas subjek hanya memiliki 1 orang anak $(57 \%)$.

Sebagian besar subjek mendapatkan informasi mengenai pentingnya nutrisi, stimulasi dan kasih sayang dalam pemantauan tumbuh kembang anak dari televisi, bidan/perawat, seminar, dan gawai/media sosial.

Perubahan sikap ibu terhadap pentingnya pemantauan tumbuh kembang balita jika dibandingkan sebelum dan setelah mengikuti seminar tertera pada Tabel 2.

Tabel 2 menunjukkan bahwa setelah mengikuti seminar terjadi peningkatan bermakna pada 5 dari 6 sikap ibu tentang pentingnya pemantauan tumbuh kembang anak. Terdapat 1 sikap yang nilainya kurang (2,23 dari maksimal 3$)$ dan tidak meningkat secara bermakna $(\mathrm{p}=0,26)$, yaitu pentingnya ibu menanyakan kemampuan anak bermain dengan anak lain dan benda di sekitarnya.

Perubahan sikap ibu terhadap pentingnya nutrisi untuk tumbuh kembang dan kesehatan balita sebelum dan sesudah mengikuti seminar tertera pada Tabel 3 .

Tabel 3 menunjukkan adanya peningkatan bermakna pada 5 dari 6 sikap ibu tentang pentingnya nutrisi untuk tumbuh kembang dan perlindungan. Terdapat satu sikap yang tidak mengalami peningkatan bermakna $(0,078)$, yaitu pentingnya makanan untuk kecerdasan dikarenakan sejak awal sikap ibu terhadap poin tersebut sudah baik $(2,59)$.

Tabel 4 menunjukkan perubahan sikap ibu terhadap pentingnya kasih sayang dan stimulasi bermain pada anak sebelum dan sesudah mengikuti seminar.

Tabel 4 menunjukkan terjadi peningkatan bermakna $(p<0,05)$ pada 5 dari 6 sikap ibu. Terdapat satu sikap ibu yang meningkat secara tidak bermakna $(\mathrm{p}=0,328)$ adalah sikap ibu bila anak tidak bisa dan memarahinya, tetapi sikap ibu sudah baik sebelum mengikuti seminar $(2,81)$. Peningkatan yang signifikan juga didapatkan setelah dilakukan analisa pada rerata 
Soedjatmiko dkk: Efektivitas seminar pada perubahan sikap ibu dalam pemberian dukungan nutrisi dan stimulasi selama pemantauan tumbuh kembang

Tabel 3. Sikap ibu mengenai pentingnya nutrisi untuk tumbuh kembang dan kesehatan balita

\begin{tabular}{|c|c|c|c|c|c|c|}
\hline No & Pertanyaan & $\begin{array}{l}\text { Sebelum } \\
\text { Rerata (SD) }\end{array}$ & $\begin{array}{l}\text { Sesudah } \\
\text { Rerata (SD) }\end{array}$ & $\begin{array}{l}\text { Beda Rerata } \\
\text { (SD) }\end{array}$ & CI 95\% & $\mathrm{p}$ \\
\hline 1 & $\begin{array}{l}\text { Pemberian ASI sampai anak umur } 2 \\
\text { tahun }\end{array}$ & $2,6(0,56)$ & $2,67(0,55)$ & $-0,08(0,52)$ & $-0,12 \sim-0,04$ & $<0,001$ \\
\hline 2 & $\begin{array}{l}\text { Makanan anak hanya penting untuk } \\
\text { pertumbuhan badan saja }\end{array}$ & $2,11(0,73)$ & $2,38(0,74)$ & $-0,27(0,79)$ & $-0,33--0,21$ & $<0,001$ \\
\hline 3 & $\begin{array}{l}\text { Makanan anak juga penting untuk } \\
\text { kecerdasan anak }\end{array}$ & $2,59(0,5)$ & $2,63(0,53)$ & $-0,04(0,55)$ & $-0,082 \sim-0,004$ & 0,078 \\
\hline 4 & $\begin{array}{l}\text { Makanan anak juga penting untuk } \\
\text { perlindungan penyakit }\end{array}$ & $2,54(0,54)$ & $2,6(0,52)$ & $-0,06(0,5)$ & $-0,09 \sim-0,02$ & 0,004 \\
\hline 5 & $\begin{array}{l}\text { Makanan anak untuk pertumbuhan } \\
\text { otak perlu mengandung minyak ikan, } \\
\text { omega } 3 \text { dan } 6\end{array}$ & $2,56(0,52)$ & $2,67(0,49)$ & $-0,11(0,51)$ & $-0,15 \sim-0,07$ & $<0,001$ \\
\hline \multirow[t]{2}{*}{6} & $\begin{array}{l}\text { Makanan anak untuk perlindungan } \\
\text { perlu mengandung serat, bakteri } \\
\text { laktobasilus, vitamin A,C,E mineral } \\
\text { selenium dan zinc }\end{array}$ & $2,5(0,54)$ & $2,66(0,51)$ & $-0,16(0,54)$ & $-0,20 \sim-0,12$ & $<0,001$ \\
\hline & $\begin{array}{l}\text { Rerata skor sikap ibu pada pentingnya } \\
\text { nutrisi untuk tumbuh kembang dan } \\
\text { perlindungan anak }\end{array}$ & $2.48(0,37)$ & $2,61(0,39)$ & $-0,12(0,33)$ & $-0,15--0,09$ & $<0,001$ \\
\hline
\end{tabular}

Keterangan: $0-0,75=$ tidak peduli; $0,76-1,5=$ sangat kurang peduli; $1,51-2,25=$ kurang peduli; $2,26-3=$ peduli. $p<0,05=$ signifikan

Tabel 4. Sikap ibu pada pentingnya kasih sayang dan stimulasi bermain

\begin{tabular}{|c|c|c|c|c|c|c|}
\hline No & Pertanyaan & Sebelum & Sesudah & $\begin{array}{l}\text { Beda Rerata } \\
\text { (SD) }\end{array}$ & CI 95\% & $\mathrm{p}$ \\
\hline 1 & $\begin{array}{l}\text { Anak umur } 1-5 \text { tahun perlu setiap hari } \\
\text { bermain bersama orangtua/ pengasuh }\end{array}$ & $2,38(0,66)$ & $2,47(0,7)$ & $-0,09(0,67)$ & $-0,14 \sim-0,04$ & 0,001 \\
\hline 2 & $\begin{array}{l}\text { Permainan anak harus dengan melihat, } \\
\text { mendengar, memegang dan membuat seuatu }\end{array}$ & $2,53(0,5)$ & $2,65(0,49)$ & $-0,12(0,51)$ & $-0,16 \sim-0,08$ & $<0,001$ \\
\hline 3 & $\begin{array}{l}\text { Ketika bermain anak perlu dipuji dengan } \\
\text { suasana gembira }\end{array}$ & $2,51(0,52)$ & $2,63(0,52)$ & $-0,11(0,54)$ & $-0,16 \sim-0,07$ & $<0,001$ \\
\hline 4 & $\begin{array}{l}\text { Jenis permainan ditentukan oleh orangtua, } \\
\text { anak tidak boleh memilih }\end{array}$ & $2,31(0,64)$ & $2,53(0,6)$ & $-0,22(0,65)$ & $-0,27--0,17$ & $<0,001$ \\
\hline 5 & $\begin{array}{l}\text { Anak harus mau dan mampu melakukan } \\
\text { permainan sesuai keinginan orangtua }\end{array}$ & $2,36(0,63)$ & $2,54(0,61)$ & $-0,18(0,59)$ & $-0,23 \sim-0,14$ & $<0,001$ \\
\hline \multirow[t]{2}{*}{6} & $\begin{array}{l}\text { Kalau anak tidak mau atau belum bisa, harus } \\
\text { dimarahi }\end{array}$ & $2,81(0,44)$ & $2,83(0,44)$ & $-0,02(0,49)$ & $-0,06 \sim 0,02$ & 0,328 \\
\hline & $\begin{array}{l}\text { Rerata skor sikap ibu pada pentingnya kasih } \\
\text { sayang dan stimulasi bermain }\end{array}$ & $2,48(0,34)$ & $2,61(0,37)$ & $-0,13(0,31)$ & $-0,15 \sim-0,10$ & $<0,001$ \\
\hline
\end{tabular}

Keterangan: $0-0,75=$ tidak peduli; $0,76-1,5=$ sangat kurang peduli; $1,51-2,25=$ kurang peduli; $2,26-3=$ peduli. $p<0,05=$ signifikan 
Soedjatmiko dkk: Efektivitas seminar pada perubahan sikap ibu dalam pemberian dukungan nutrisi dan stimulasi selama pemantauan tumbuh kembang

Tabel 5. Sumber informasi peserta tentang pentingnya pemantauan tumbuh kembang, pentingnya nutrisi dan pentingnya kasih sayang-stimulasi

\begin{tabular}{lccc}
\hline & $\begin{array}{c}\text { Pentingnya pemantauan } \\
\text { tumbuh kembang } \\
\mathrm{n}=617\end{array}$ & $\begin{array}{c}\text { Pentingnya nutrisi untuk } \\
\text { tumbuh kembang } \\
\mathrm{n}=617\end{array}$ & $\begin{array}{c}\text { Pentingnya kasih sayang-stimulasi } \\
\text { untuk tumbuh kembang } \\
\mathrm{n}=617\end{array}$ \\
Sumber informasi & $139(22,5)$ & $\mathrm{n}(\%)$ & $\mathrm{n}(\%)$ \\
\hline TV & $5(0,8)$ & $121(19,6)$ & $181(29,3)$ \\
Radio & $59(9,6)$ & $2(0,3)$ & $4(0,6)$ \\
Majalah/tabloid/koran & $14(2,3)$ & $70(11,3)$ & $74(12,0)$ \\
Penjual Supermarket/toko & $111(18,0)$ & $17(2,8)$ & $1(0,2)$ \\
Gawai/media sosial & $111(18,0)$ & $106(17,2)$ & $112(18,2)$ \\
Seminar & $45(7,3)$ & $82(13,3)$ & $121(19,6)$ \\
Dokter & $114(18,5)$ & $72(11,7)$ & $15(2,4)$ \\
Perawat/ bidan & $17(2,8)$ & $130(21,1)$ & $57(9,2)$ \\
Lain-lain & $2(0,3)$ & $16(2,6)$ & $46(7,5)$ \\
Tidak ada & & $1(0,2)$ & $6(1,0)$ \\
\hline
\end{tabular}

umum nilai sikap Ibu sebelum $(2,44 \pm 0,30)$ dan sesudah $(2,58 \pm 0,32)$, beda mean $-0,15 \pm 0,26$; interval kepercayaan (95\%) -0,17sampai-0,13; nilai $\mathrm{p}<0,001$.

Tabel 5. memperlihatkan sumber informasi peserta mengenai pentingnya pemantauan tumbuh kembang, pentingnya nutrisi, stimulasi dan kasih sayang. Berdasarkan hasil penelitian, informasi paling sering didapat dari televisi, gawai, media sosial, tenaga kesehatan (perawat dan bidan), serta mengikuti seminar oleh tenaga kesehatan.

\section{Pembahasan}

Penelitian ini dilakukan di 6 kota besar di tiga pulau besar yang salah satunya merupakan pulau dengan populasi tertinggi di Indonesia. Pemilihan lokasi penelitian dapat merepresentasikan Indonesia secara umum. Populasi target pada penelitian ini adalah ibu yang memiliki anak balita, mengingat dalam pengasuhan anak, ibu merupakan komponen terdekat dalam ekosistem mikro anak yang memiliki pengaruh besar dalam pertumbuhan dan perkembangan anak. Selain itu, balita merupakan kelompok usia anak yang masih sangat tergantung pada pengasuhnya sehingga kecukupan kebutuhan nutrisi dan stimulasinya sangat bergantung pada pengasuh termasuk ibu. ${ }^{10}$

Stimulasi adalah rangsangan yang dilakukan oleh keluarga melalui interaksi bermain yang menyenangkan dan penuh kasih sayang. Stimulasi harus merangsang penglihatan, pendengaran, kognitif, gerak kasar halus, berupa contoh, perintah, melakukan suatu gerak bertujuan sehingga mengembangkan kemampuan kognitif, kreativitas, pemecahan masalah. Stimulasi sebaiknya menggunakan berbagai sarana yang ada di dalam dan sekitar rumah. Anak diberikan kesempatan memilih permainan yang disukai, dilakukan dalam suasana gembira, dilandasi oleh kasih sayang disertai pujian, tidak dipaksakan untuk mencapai hasil tertentu. Oleh karena itu, orangtua terutama ibu harus mengerti cara melakukan stimulasi bermain tersebut untuk mengembangkan semua potensi anak. . $^{611,12}$

Sikap ibu dalam pengasuhan anak dipengaruhi oleh berbagai faktor, seperti pengetahuan, tingkat pendidikan, jumlah anak (pengalaman mengasuh anak) dan keadaan ekonomi keluarga. Pengetahuan dan tingkat pendidikan ibu menjadi penentu sikap dan perilaku yang ibu lakukan dalam pemberian nutrisi, kasih sayang, frekuensi dan stimulasi yang diberikan ibu kepada anaknya. Tingkat pendidikan dan pengetahuan ibu, terutama mengenai tumbuh kembang anak memiliki peran yang besar dalam usaha mengoptimalkan kesehatan anak. Chou dkk ${ }^{3}$ menyebutkan bahwa terdapat hubungan yang erat antara tingkat pendidikan ibu dengan kesehatan anaknya. Sementara itu, penelitian lain melaporkan tingkat pengetahuan ibu mengenai perkembangan anak sangat penting, terutama pada anak usia dini. ${ }^{13}$ Pada penelitian ini, lebih dari 90\% ibu memiliki pendidikan setara SMA ke atas sehingga penerimaan informasi ibu cukup baik, terbukti dengan adanya peningkatan nilai sikap jika dibandingkan antara pre dan post 
seminar. Hal tersebut sangat penting mengingat ibu berperan penting dalam pengasuhan anaknya sehingga diharapkan pengasuhan yang dilakukan akan lebih baik. Pada penelitian ini, lebih dari tiga perempat ibu mengasuh anaknya secara langsung.

Status ekonomi dan jumlah anak juga berperan penting dalam pembentukan sikap ibu. Ibu yang bekerja di luar rumah tidak memiliki cukup waktu untuk memberikan kasih sayang yang adekuat. Di satu sisi, Bornstein $\mathrm{dkk}^{14}$ menyebutkan bahwa kemampuan seorang ibu dalam mengasuh anak akan berkembang dari anak pertama ke anak kedua, dan seterusnya. Namun, jumlah anak yang banyak juga berpengaruh pada pemenuhan kadar nutrisi, intensitas kasih sayang, dan frekuensi stimulasi pada masing-masing anak. Pada penelitian ini, lebih dari 50\% ibu tidak bekerja dan $57 \%$ baru memiliki anak satu orang.

Seminar merupakan salah satu metode edukasi untuk memberikan pengetahuan tambahan kepada subyek peserta. Seminar kesehatan terbukti meningkatkan pengetahuan ibu pada topik-topik kesehatan. Studi di China dilaporkan bahwa setelah mendengarkan seminar, terjadi peningkatan bermakna pada pengetahuan ibu tentang vaksinasi. Setelah mengikuti seminar, nilai rerata 10 pertanyaan dalam kuesioner meningkat dari 5,2 $\pm 1,2$ poin menjadi $8,4 \pm 0,9$ poin. Pada studi tersebut dilakukan analisis univariat dan didapatkan beberapa faktor yang memengaruhi efektivitas seminar dalam meningkatkan skor pengetahuan ibu tentang vaksinasi, antara lain, faktor tingkat pendidikan, status kependudukan, status pekerjaan (bekerja/tidak bekerja) dan penghasilan rumah tangga per bulan. ${ }^{2}$

Penelitian ini memperlihatkan bahwa sumber informasi yang dianggap penting dan berkesan untuk ibu, baik mengenai pentingnya pemantauan, nutrisi, stimulasi dan kasih sayang, agar tumbuh kembang anak optimal adalah televisi, gawai, media sosial, tenaga kesehatan (perawat dan bidan), serta mengikuti seminar oleh tenaga kesehatan. Penelitian ini memperlihatkan bahwa terjadi peningkatan sikap ibu setelah mengikuti seminar yang diadakan oleh peneliti. Sejalan dengan hasil survei tentang sumber informasi yang penting dan berkesan bagi ibu adalah seminar oleh tenaga kesehatan. Penelitian ini membuktikan bahwa pemberian seminar oleh tenaga kesehatan dapat mengubah sikap ibu mengenai pengasuhan anak yang terdiri atas pemantauan tumbuh kembang, dukungan nutrisi, dan pemberian kasih sayang serta stimulasi.
Penggunaan teknologi dalam pemberian edukasi cukup beragam dan dapat dijadikan salah satu pilihan dalam penyampaian edukasi untuk ibu. ${ }^{15}$ Penelitian ini juga memperlihatkan bahwa sumber informasi yang dianggap paling penting dan berkesan adalah televisi, gawai, dan media sosial. Peran media elektronik dan media sosial yang menggunakan teknologi yang lebih canggih perlu ditingkatkan lagi sebagai sarana pemberin informasi tentang kesehatan anak bagi ibu. Penggunaan televisi dan sosial media dapat meningkatkan jumlah ibu yang mendapatkan informasi dibandingkan penyampaian informasi melalui media seminar.

Edukasi yang dilakukan dalam bentuk seminar, tanya jawab, konseling, berperan membentuk sikap Ibu. Edukasi berupa konseling terbukti dapat mengubah sikap ibu terkait pemberian nutrisi, dan perbaikan nutrisi anak. Dalam studi yang dilakukan di Semarang pada 278 anak didapatkan peningkatan kurva dan stabilitas kurva $Z$-score berat badan berdasar umur dan tinggi badan berdasar umur pada kelompok yang ibunya diberikan konseling dan pendampingan nutrisi dibandingkan dengan kelompok yang ibunya tidak mendapatkan konseling tentang nutrisi (. Bahkan kurva $Z$-score berat badan berdasarkan usia pada kelompok kontrol (tidak mendapat konseling) cenderung turun. ${ }^{6}$

Hasil penelitian ini menunjukkan adanya peningkatan bermakna pada hampir seluruh sikap ibu terhadap pentingnya nutrisi, stimulasi, dan kasih sayang dalam pemantauan tumbuh kembang anak. Pada aspek penting pemantauan tumbuh kembang balita, sikap ibu mengalami perubahan positif pada seluruh pertanyaan pada kuesioner selain mengenai perlunya menanyakan kemampuan anak bermain dengan benda dan anak lain ketika ke dokter/ Puskesmas/ Posyandu. Sikap ibu terkait dengan hal tersebut masih perlu ditingkatkan lagi. Sementara itu, untuk aspek pentingnya nutrisi, stimulasi dan kasih sayang, terdapat beberapa poin yang tidak terjadi perubahan dikarenakan sikap ibu sudah cukup baik terhadap poin-poin tersebut sebelum seminar. Perubahan sikap ibu yang bermakna membuktikan bahwa seminar mengenai pentingnya kasih sayang dan stimulasi bemain untuk mengembangkan potensi anak terbukti bermanfaat meningkatkan sikap ibu pada hal tersebut. Penelitian ini memiliki beberapa keterbatasan, antara lain, tidak adanya kelompok kontrol. Hal ini sesuai dengan kriteria inklusi, yaitu 
semua subjek merupakan peserta seminar kesehatan anak. Dari 1090 ibu yang mengikuti seminar hanya 617 ibu yang dapat masuk sebagai subjek sesuai kriteria inklusi dan eksklusi.

\section{Kesimpulan}

Seminar yang dilakukan oleh tenaga kesehatan terbukti efektif mengubah sikap ibu tentang pemantauan tumbuh kembang, dukungan nutrisi dan pemberian kasih sayang serta stimulai dalam pengasuhan anak. Perubahan sikap ibu ini diharapkan akan diikuti dengan perubahan perilaku ibu dalam mengasuh anak mereka. Pemberian edukasi kepada ibu dapat pula disampaikan melalui media teknologi ataupun media sosial untuk percepatan penyebaran informasi.

\section{Ucapan terima kasih}

Ucapan terima kasih dihaturkan kepada seluruh Ibu yang telah berpartisipasi dalam penelitian dan juga kepada Gardini Oktari, dan Emi Triana Putri yang telah membantu terlaksananya penelitian ini, serta kepada dr. Ovamelia Julio yang membantu dalam penulisan. Penelitian ini merupakan penelitian kerjasama antara Departemen Ilmu Kesehatan Anak dengan Dancow Parenting Center (DPC) PT. Nestlé Indonesia.

\section{Daftar pustaka}

1. $\mathrm{Hu}$ Y. Does an education seminar intervention improve the parents' knowledge on vaccination? evidence from yiwu, east china. Int J Env Res Pub He 2015;12: 3469-79.

2. Noviati N, Susanto J, Selina H, Mexitalia M. The influence of intensive nutritional counseling in Posyandu towards the growth 4-18 month old children. Paediatr Indones 2016;46:57.

3. Chou S, Liu J, Grossman M, Joyce T. Parental education and child health: evidence from a natural experiment in taiwan. Am Econ J Appl Econ 2010;2:33-61.

4. Winter P. Engaging families in the early childhood development story. Carlton South: Ministerial Council for Education, Early Childhood Development and Youth Affairs; 2010.

5. Astarani K, Werdiningsih ATA. Peran ibu dalam pemenuhan kebutuhan dasar anak terhadap perkembangan anak usia prasekolah. Jurnal Penelitian STIKES Kediri 2010;5:82-9.

6. Soedjatmiko. Pentingnya stimulasi dini untuk merangsang perkembangan bayi dan balita terutama pada bayi risiko tinggi. Sari Pediatri 2016;83:164.

7. National Academies of Sciences, Engineering, and Medicine. Parenting matters: supporting parents of children ages 0-8. Washington, DC: The National Academies Press; 2016.

8. Lee HS (2016). Research trends in mothers' health information seeking behaviors: a review of the literature. Proc Assoc Info Sci Tech 2016;53:1-6.

9. Sumargi A, Sofronoff K, Morawska A. Understanding parenting practices and parents' views of parenting programs: a survey among Indonesian parents residing in Indonesia and Australia. J Child Fam Stud 2013;24:141-60.

10. Nelson S, Kushlev K, Lyubomirsky S. The pains and pleasures of parenting: When, why, and how is parenthood associated with more or less well-being?. Psychol Bull 2014;140:846-95.

11. Yarrow LJ, Rubenstein JL, Pedersen FA, Jankowski JJ. Dimensions of early stimulation and their differential effects on infant development. Merrill-Palmer Q Beh 1972;18:205-18.

12. Powell L. The effect of extra stimulation and maternal involvement on the development of low-birth-weight infants and on maternal behavior. Child Dev 1974;45:106.

13. Ertem I, Atay G, Dogan D, Bayhan A, Bingoler B, Gok C, dkk. Mothers' knowledge of young child development in a developing country. Child Care Hlth Dev 2007;33:728-37.

14. Bornstein M, Cote L, Haynes O, Hahn C, Park Y. Parenting knowledge: Experiential and sociodemographic factors in European American mothers of young children. Dev Psychol 2010;46:1677-93.

15. Hall C, Bierman K. Technology-assisted interventions for parents of young children: Emerging practices, current research, and future directions. Early Child Res Q 2015;33:2132. 